\title{
Iqbāl's Position on Reconstruction of Religious Thoughts in Islam
}

\section{Salahuddin Mohd. Shamsuddin}

\author{
Faculty of Arabic language, Sultan Sharif Ali Islamic University \\ Brunei Darussalam \\ Corresponding author details: Prof. Dr. Salahuddin Mohd. Shamsuddin; \\ shamsuddinsalahuddin@gmail.com
}

\begin{abstract}
Muhammad Iqbāl's book: Reconstruction of Religious Thoughts in Islam was published in English first time in Lahore in 1930 and then translated into Arabic. This book contains a collection of his six lectures that were delivered by Iqbāl in Madras and Hyderabad. These lectures were collected under the title: "Reconstruction of Religious Thoughts in Islam". It is the biggest intellectual wealth left by Iqbāl. In his philosophical style, Iqbāl has addressed those topics that are related to the Islamic sciences, spiritual experiences, Existence of God Almighty, the reality and the nature, the human self, reparation, the choice, the spirit of Islamic civilization, the diligence and development of Islamic law. It seems that Iqbāl's character appears in this book as an Islamic thinker and philosopher, in which we see him as he wants to develop a new Islamic science of speech. Iqbāl addressed these topics by the careful research and deep study in the light of Islamic knowledge and modern philosophy, and opened the doors of thinking about Islam to the contemporary thinkers and scholars in various fields. First of all, it is important to us to study his Islamic thought so that we can understand his poetry, which he wanted to put in the service of Islam, so we cannot ignore to study his seven lectures written in prose on the reconstruction of religious thoughts in Islam, as we think that the scholar cannot reach the spirit of his poetry and the depth of his thought without studying those lectures.
\end{abstract}

Keywords: Lectures of Muhammad Iqbāl; Reconstruction of religious thought; Human self; Spirit of Islamic culture; Approach of Knowledge in Islam

\section{INTRODUCTION}

Iqbāl's Book: "Reconstruction of Religious Thought in Islam"

Iqbāl delivered some lectures on this subject and published them in a book, to help in understanding Islam correctly as a message to all humanity, and there is no doubt that Iqbāl in this book called the Islamic nation to think about Islam again, so we have to ask to know the following:

A. What are Iqbāl's motives for renewing the religious thinking in Islam?

B. What does Iqbāl mean by renewing the religious thinking?

C. Does he mean reassessing the facts emanating from the religious perception again and again under the influence of renewed philosophical thinking?

D. Or does he mean a continuous reconciliation between the topics of religious faith and Islamic thought, whenever it achieves a development in its career and achievements?

Whatever the right answer, the religious thought cannot be balanced, but only in the light of this reconciliation between the developments of thought and reason and the occurrence of religious experience.

Motives for Renewing Religious Thought to Iqbāl Muhammad Iqbāl's motives for renewing religious thought are different, some researchers have argued that he received from the kinds of human cultures that opened his eyes and thought on the real stage in the East and West, and what he saw here and there some factors of prosperity, growth and development and some factors of stagnation, inactivity and deterioration, and saw the disparity between the East and West or between Islamic countries and Western countries, he felt the pain and tension increased in himself under the influence of two factors:

A. Political factor, which is the Imperial domination that has taken the stranglehold of the Eastern peoples in general and the Muslim peoples in particular, and the aggression, enslavement and brutal harnessing of the People in India under the English rule.

B. Religious factor, which is the stark contradiction between the reality of Muslims and the reality of their religion. Iqbāl kept in the depths of his mind and conscience that wonderful image of Islam, while those Muslims who took the formalities of this religion are seen in the lowest realities of decadence and backwardness, so the true spirit of Islam and the social reality of Muslims were the main motives that woven the threads of his reformist idea, and his regenerative attempt.

There is no doubt that he wanted to study and analyze first the reality of Muslims in India and found that the motives for their backwardness were as follows:

1) General ignorance of successful lifestyles, foremost of which is ignorance of practical sciences, civic methods and social organization.

2) The corruption of the faith, the transformation of Islamic monotheism into a hidden paganism behind 
3) the worship of saints, the sanctification of shrines, the appreciation of charlatans and witches, and the attraction of illusions.

4) Asceticism in life, the spread of monasticism and Sufi methods, the spread of the limestone, laziness and dependency spirit, people stopped working, surrendered to the destinies in despair and were led like mocking ostriches directed by whom he wanted and how he wished.

5) Young Muslims were fascinated by the western civilization, dazzled by its power, charms and beauty, as they have in fact found their parents and communities nothing but death and despair, and are happy to live, narrow their ambitions and stifle their hopes.

These issues, in Iqbāl's view, constitute some psychological barriers to rebirth and exit from underdevelopment, and create a stark contradiction between a generation that believes in the past and closes its eyes to the present, and another generation that disbelieves in the past and perishes over the present.

After witnessing this chronic and inaction situation, which is full of contradictions, Iqbāl outlined the measures that the trial seeks to analyze and treat. There is no doubt that as a reformer or pioneer of reform, his nation was seen through the eyes of the West. It analyzes the conditions of backwardness compared to the West, through the modern thinking itself, i.e. he made up the Western logic in assessing the situation, but he was not fooled by the civilization of the West or the human being of the West, because he was able to distinguish in the Western civilization between two different things in his view.

First is the movement of scientific progress that is growing thanks to the modern scientific approaches, and beyond the constant pursuit of innovation, creativity, detection and invention in order to control the nature, and harness its laws for the human life.

Second is imperialism and materialism, accompanying manifestations of racist, material and atheistic tendencies, which are in the hearts of Europeans. All this was represented to him in the Western colonial movement, which surrounded the underdeveloped world, absorbed its bounties, mocked its people, and judged to power and benefit without regard to the honor, humanity or faith.

This distinction between the contradictory elements in the structure of Western civilization, set for him a trend line in building his regenerative attempt. First, he believes in the self-identity of Islam, its original genius and its ability to provide the Muslim with full effectiveness to return to reality and test it, and control it, without backwardness or tradition of Western civilization in its moral tendencies or social doctrines, on the other hand, he believes in the genius of science, and the objective results of the scientific curricula of the West, which are a gain for all the humanity, as they were the objective approaches and results of science among the Muslims a gain for all the humanity and the basis of modern Western civilization.

This comprehensive vision, based on comparing the life in the East, in which the religion is suspended, with the life in the West where the science is separated from the religion, made him to stand on the positive elements that ware lost. From this vision emerged the idea of Iqbāl and his attempt to renew the building of religious thought in Islam.

He certainly sensed the intellectual emptiness that a young Muslim finds in the dominance of Western thought, because Islamic origins have to be accompanied by a process of scrutinizing the results of Western thought, to turn the results into a positive factor in deepening religious thought, because Islamic science of speech had stopped growing and developing, it remained at the level of current mental developments. On the other hand, he sought to stop the current of atheism among the young Muslims educated in Western culture, by offering a new understanding of religious thought that reveals the true essence of Islam.

\section{Objectives of Renewal to Iqbāl}

The first objective of this renewal, and the reason that Iqbāl wanted to give this objective, is to find a mental basis for the fundamental principles of Islam, because he believes that the religion hardly dispenses with the quest to reconcile the contradictions we find in the world of experience, and believes that the religion hardly dispenses with an explanation that justifies the conditions of the environment in which the humanity finds itself surrounded. In this position, he supports the English philosopher Hieghthood in his view that the faith flourishes only in the age of mental consideration.

Iqbāl was seeking to transform the religion from mere theoretical knowledge to an applicable knowledge to the religious experience itself, in the context of what was tried by 'Abu Hāmid al-Ghazāli in the past. This is the religion at its highest level, but achieving this goal is not easy. We therefore see him insisting on the importance of this religious experience, and believes that it is the basis for revealing the eternal truth, the balance between the intuition and reason in the life of Muslim, and that it is the center of gravity in the creative cultural construction of Islam, and a wonderful and bright civilization.

\section{Iqbal's idea and philosophy for the renewal}

Iqbāl did not actually intend to present an integrated philosophy for a distinct philosophical doctrine, but he intended what he expressed at the forefront of his lectures to build a new building of Islamic religious philosophy taking into account the adage of the philosophy of Islam, as well as the development of human knowledge in its various aspects.

It is clear from Iqbāl's position that he tried to formulate the religious thought with a philosophical formulation in which he combined the origins of Islam with the approach of Western philosophy. In the foreground of his lectures, he declares that he does not provide a final formulation or final solutions to the dilemmas that he has raised, because the philosophical thinking has no limit to him, and perhaps it is possible that we can find some healthier opinions than his opinions that he has presented. Therefore, he believed that the man must remain in touch with what the human thought offers, and the man must stand in the position of criticism and scrutiny.

It is understood that Iqbāl was a poet because of his intellectual tendencies and psychological preparations and because of his aspiration for the truth, his deep sense as being the first human demand, then the deep religiosity, commitment to Islam, and his insight into many religious realities added to him a visible ability to combine these events to formulate an idea in which the elements of philosophy, religion and poetry do not diminish, although it cannot be done actually but on the basis that one works for the other, these three means end with a intuition that appears each time in a special appearance.

The first questions raised by Iqbāl in the introduction to his lectures take the form of fundamental questions that are contained in the first lecture "The knowledge and the religious experience": 
What's the nature of the universe and where do we operate? What kind of behavior is consistent with this subject?

However, the researcher notes that the answer is not related only to the philosophy but also, they can be sometimes answered in the form of some poetic reflections or some religious experiences.

So Iqbāl declares at the entrance to his lectures that these issues are shared among the religion, philosophy and high poetry. He then adds that the knowledge inspired by the poetry is necessarily personal (he wants to say that it is an individual experience) as its type and nature, which is vague and unspecified metaphor. Religion (in its entire vision) is above the poetry, as it goes from the individual to the community. He means that the religion gives a picture that is appropriate to the collective thought, and in its position on the whole truth it is contrary to man's inability and shortcomings, because it opens the horizons to his demands, and makes him to hold with a great hope, which is not less than who see the truth directly.

Religion in this perception of Iqbāl does not feel about the human as the philosophy feels about him - in most of its doctrines - that he is a lost being, which has nothing to do with the universe except in terms of this arbitrary presence that it threw him at the moment of consciousness between two absolute non-existents: pre-life and beyond this life; but he is existed by the will and existed for a target to be achieved purposely. Then he's rewarded with the full reward. (1)

Here is an essential difference that the religion cannot prove its facts without its intuition, and without opening the insight to it in a vision or an image and a total sentimentality, whereas philosophy takes the mind step by step, towards the realization of those facts with their deepness. The question here is what Iqbāl said in this way: Is it possible, then, to use the purely mental approach of philosophy in the investigations of religion?

Iqbāl tried to use this approach, but he could not overcome the uncertainty, rebellion and freedom that does not know the limits. Therefore, we find him saying, in a tone that shows distrust of the success of the mind in this task: "The spirit of philosophy, which is a free research puts everything in doubt, its function is to investigate the assumptions of human thought that have not been examined by the criticism to its depths, and may end its search for denial or to explicitly acknowledge the inability of purely mental thinking to be shrouded in the extreme truth."

"In the face of this destructive power or the senseless weakness of the mind, Iqbāl chooses to keep the truth religious, a scholarly poet, a philosopher, based on his impotence, saying: "The essence of religion is the faith, and the faith is as a bird knows its way free from the world, not guided by the reason."

Muhammad Iqbāl's quest for a new formation of the credibility of Islam can be summarized as follows:

1) A new formulation of the Islamic faith, and in this area established some new principles of Islam in the light of the contents of the Holy Qur'an and philosophical and scientific thought, addressing the issues of faith in God, faith in the resurrection, and belief in the all contents of Islamic monotheism, including the doctrine of justice and destiny.

2) Formulating some new principles for the morality of the Muslim individual, and in this area defines the new values that can make the Muslim sufficient effectively and dynamically creatively, giving the work and self-control and seeking self-perfection and jihad a new approach.

3) Renewing or reviving the creative elements in Islamic in order to go along with the evolving life of a Muslim, by insisting on opening the door to the diligence. The use of unanimity as an asset of legislation covers all new needs in the world of Muslim and his society.

\section{Methodology of knowledge in Islam according to Iqbāl} Iqbāl addressed the problem of knowledge of the texts of the Qur'an, as he tried in the beginning of his lectures that were delivered on "Reconstruction of religious thoughts in Islam" to look for the nature of knowledge and its approach in Islam, and relied in his research on the Qur'anic texts, as he reviewed several Qur'anic verses, including:

God Almighty said: "We did not create the heavens and the earth, and the players between them. We did not create them, but with the truth, but most of them do not know. (2)

God almighty saying: "There is the creation of heavens and earth, and the difference of night and day, that are some signs for the thinkers. Those who remember God in their standing, sitting and the other situations and think about the creation of heavens and earth, our Lord, did not create this false". (3)

God almighty saying: "Say walk in the earth, look at how the creation started, and then God creates the afterlife. No doubt that God Almighty is able to do anything" (4)

Iqbāl concluded from these verses the following results:

1) The Qur'an believes that the world is an area of consideration and reflection and that it is subject to a fixed system, that it was not created in vain, and that it must be taken into account.

2) The nature of man represents to know this world. This nature is a positive nature, because the man is a concerned being eager to know, who has a great responsibility on his shoulders, and he will reach the truth as well as he can. (5)

After that Iqbāl says while relying on the text: "Man's existence and his spiritual progress depends on the strong relationships between him and the truth that he faces, and these relationships are created by the knowledge, which is mental awareness".

"And when your Lord told the angels that I am making a caliph on the earth they said I make someone spoil it and shed blood while we praise you and we sanctities you, he said I know what you do not know. And taught Adam all the names and then presented them to the angels and said: "Tell me the names of these if you are honest. They said glory be to you, we do not know, but only what you have taught us, no doubt that you are the wise one. He said: Oh Adam, "Tell them their names, and when he told them their names, he said, "Didn't I tell you that I know the absence of heavens and earth and I know what you show and what you are hiding?" (6)

These verses indicate that the man is able to put names for the things, and that he is equipped with this talent that gives him this ability. So human knowledge is cognitive, and because of this knowledge, the man realizes what is observable from the truth. There is no doubt that the first target of this contemplative observation of nature by the Qur'an is that it gives the same man a sense that this nature is a sign of this feeling. But what should be noted 
is the general experimental trend of the Qur'an, which has provided its followers a sense of evaluation of reality, and has finally made them the founders of basis of modern science, and it is truly great that the Qur'an has awakened that experimental spirit in an era when the visual world was rejected as a poor source of the human research about the Creator. (7)

Iqbāl concludes from the Qur'anic texts the method of knowledge in Islam, and he depends in his approach on the observation and experience, and then decides that knowing the truth is a matter available through the means provided to the man in his instinct, his senses, and his mind, such as the observation, sensory perception, experimentation and inference, and then also decides that the truth lies in the same physical manifestations. In doing so, he pointed out that it is wrong to ignore the material world, which has all the facts hidden inside, and that ignoring the material inevitably leads to the failure of culture as well as the cultures of Asia and the cultures of the whole old world, because it dealt with the truth with mental consideration, and then turned from it to the outside the world and provided it with this course of theoretical thinking without the power, and it is not possible that a civilization based on abstract consideration alone can survive. (8)

\section{When Iqbāl raises these questions:}

- What are the means of knowledge in Islam?

- What is the value of the mind in the field of knowledge?

- Does the mind have absolute access to knowledge?

- Can the mind reach all the facts?

We find that he determines his position on these principled questions indeed, but it falls in contradiction or hesitation between the faith in reason, and the faith in Sufi trends that are the fruit of insight, and we see him hesitant between the reason and religious conscience or what Iqbāl calls the religious experience.

He sometimes declares that there is no contradiction between the idea and intuition necessarily, they stem from one origin, each complementing the other, because one of them realizes the truth partially, and the other realizes the all truth in one step, and each of them needs the other to renew its strengths, and reaches the truth that is revealed in front of the other, each of them has its way, but in the end he declares that intuition is only a kind of high thinking as Bergson (9) believes and sometimes he declares saying: The failure of the mind to understand the whole truth lies in its lack of awareness of the countless scattered particles, and that these particles are not organized by unity for it This deficiency makes us to doubt that the mind can reach a full and final understanding of the truth, because its method based on the generalization is nothing but some fictitious units that do not affect the reality of the things actually. (10)

We also see him declare elsewhere: It is wrong to think that the thinking is unable to reach the conclusive judgments, so it is also able to come to know something infinite that is broadcast in the existence, but by its own way. (11)

In light of this tendency, Iqbāl decides that one of the means of communication between us and the truth is the meditative observation of the phenomena that indicates that fact. As nature's phenomena demonstrate the laws of nature in the science, they also reveal their supreme reality in the field of religion. However, in the field of science, the connection between us and natural phenomena is indirect, i.e. externally. In the area of religious experience, the connection between us and the truth that we intend to understand is direct, i.e. mystical. The same is the area to see it by the eye and being seen and perspective, and the means of such contact is the heart. This is where Iqbāl asserts that the heart has a hidden force that cannot be overlooked simply because it is an extraordinary force, imaginary or hostage to the Sufi exercise, but it is not less effective than any other means.

Iqbāl insists on giving the religious experience the same objective value as the scientific experiment, and that such religious experience also is subject to scrutiny and criticism. Iqbāl mentioned an example of Ibn Șayyād's talk, which is narrated by al-Bukhārī and Muslim in their books of true Hadìth. (12)

However, Iqbāl notes that they both are similar in need of interpretation, and differ in that the religious experience is aware of the full truth and the scientific experience is aware of partial facts, and that the former is inextricable, indescribable and cannot be conveyed to the others; because it is an individual experience that its content can only be disclosed after it is formulated in an intellectual form.

In fact, Iqbāl considers that the experience has two areas:

- The field of the physical world or natural science that depends on the mind.

- The field of the spiritual world or the God gifted science depends on the ability to detect and conscience of the heart.

As Iqbāl says: "If we wanted to scrutinize, we would say that the experience that leads to this detection is not a conceivable mentality, but a vital fact, a tendency arising from an internal biological transformation that cannot be captured in the context of logical sayings. (13)

Iqbāl differentiates between the nature of the two experiments: scientific and religious, and emphasizes that the world usually remains isolated from what it experiences. The world before the nature is separate from its information.

There is therefore a knowledge that is composed among a set of direct sensations that coordinate the mind among themselves to give us an identical perception of the physical world. A knowledge that reveals the heart at once through the religious experience makes us feel the whole truth with all our feelings. This is the nature of knowledge in Islam, it is an awareness of the nomenclature of nature, based on observation and experimentation, and then transcends material phenomena to beyond a comprehensive cosmic system that indicates the existence of God.

The nature of knowledge in Islam does not accept the fragmentation between its material and spiritual ends. The knowledge that reveals the laws of nature and does not give the man a sense of who is considered by this nature to be a sign for his existence, for its seriousness and for its ability is incomplete and sterile knowledge, and the knowledge that transcends cosmic phenomena and dives into the occults of being silenced only by the absolute truth and ignores the material world is an abstract knowledge, and fails at the same time.

The means of knowledge are the reason and the heart, i.e. the thought and intuition, because they are complementary in the end, the divine truth is sometimes aware of the mind, and sometimes with the sense or the religious insight. (14) 
Iqbāl builds this knowledge again in the same Muslim who has been attracted by the materialism and misled by the atheistic philosophies, thus trying to build a new science of speech.

The mind and the heart or the mind and the religious text have been a means of knowledge in speech science in the past, which imagines the subject of the research of ancient speakers that rises in its mental formulation to the level of the requirements of modern thought. To that end, Iqbāl addressed the proof of God's existence and the proof of prophecy again.

\section{Freedom of the Human Self and Its Immortality to Iqbāl} Before we see how Iqbāl proves the existence of the deity of God almighty by the mental proof, it is advisable for us to shed some light on the perception of the deity of God Almighty and the same of human being.

Ibn 'Arabī, the founder of the doctrine of "Unity of existence" or (Pantheism), said that the deity of God almighty is a certain reality, and outside the space of definition, yet every human being imagines it according to the level of his perception and Cognitive abilities. It can be almost similar or completely different between what the man imagines and the truth of the divine self, even if God almighty Himself showed us, and we saw Him by our own eyes, we disagreed in His definition and characterization according to our talents and mental abilities.

There is no doubt that every human being imagines the same God Almighty according to his innate readiness and intellectual level. The farmer is different to Plato, Hegel and the others like them in the perception of the same God, because the farmer imagines God Almighty in his image, as well as the man usually sees Him like him, but the scientist or the philosopher sees Him out of the way of thinking and definition, and beyond the limits of time and space, and he sees Him higher and greater than all the assets in the universe, Therefore, there are many words used to express the same God Almighty. According to the Qur'an, "He has good names" and according to the philosophical terms, $\mathrm{He}$ is the reference to all things and their facts, and "all the things return to Him", and what is mentioned in the attributes of God Almighty in the Holy Qur'an, some of them we mention here: The will, the power, the wisdom, the lover, beloved, the beauty, the truth, the good, and the enforcement of the morality system, the beginning, and the return point, the life, the creator, the Lord, etc. He is the one, as there is no God but the one who has no partner, and he is all integral.

The poet imagines God as a poet. As the poet Browning said, "He is the greatest poet in the universe, and this world of colors and smells is His eternal tone." "Or, as the poet William Wallison said: "God is the greatest poet on His Majesty's throne, and all beings move on his tone." God is imagined by some philosophers such as Aristotle said: (He is thought and imagine for Himself). The others said: "God is the pure self that establishes and evaluate the essence and its recipes." Some followers of "Veda" the Holy Book of Hindus said: "God has a deity devoid of the qualities, and He has no relation to the movement means that He is the absolute stillness. The kinetic aspect of Divine Self is just a trick to look at."

William James, a renowned religious psychologist, portrays God as the god of desperate, failed and defeated people in their lives, because God is nothing more than the court of justice that most people resort to, to ask Him about their failure in worldly matters against public opinion. The philosopher Plato and the wise (Fithaghorth) see Him as an engineer.
As well as a German Sufi also sees that He is as just a voice that comes out of the depths of hearts. Emerson also supported who says that the divine self is an absolute soul: (Who eats the meat of a human being he imagines Him in his image, the warrior or the fighter imagines Him in his image, and the merchant in his image).

Iqbāl, such as these philosophers, has a particular perception of divine self, he is contrary to all those Greek and ancient Western perceptions that offer God in terms of the name of the attribute, Iqbāl tries hard to prove that God has a unique divine self, as mentioned in the heavenly sematic religions, He believes in the unity of the divine self, but he contradicts the theory of unity in the abundance, i.e. theory of (Pantheism). Where he says in one of his lectures:"If we use our minds to imagine the divine self, we say that the result is the unity in abundance, means (The All is He) in Persian or (unity of existence) in Arabic. Therefore, we see him using both the mind and the heart in the perception of the divine self, as the heart is the conscience or the eye of the subconscious." (15)

Iqbāl does not satisfy that the word "God" can be used for the divine self, because its collective noun (plural) is (gods), it is likely to be called "God", which is mentioned in the Holy Qur'an or as mentioned in the Bible (Jehovah) as the name of the same God meaning divinity or deity. However, God in Greece was called merely a material (Thyyun) meaning divinity or deity, and there were some other single names for the different gods such as Mercury, Flowers and the other stars.

Iqbāl imagines the same God in the unlimited form of (the greatest individual), and He is above all beings and assets, and He has an unlimited will and power to create, which is represented by the image of an individual has the infinite potential that means that $\mathrm{He}$ is the divine self or He is God Almighty or (the greatest individual) to Iqbal. He creates a lot of (Individuals) or countless individuals, and every individual lives and moves in the movement of his creation permanently, and everyone has his own essence, which is the freedom, because God is free, every individual can participate in the work of creation of the Great Creator (Allah).

When Iqbāl imagines the divine self (God Almighty), he imagines first that He has the will and imagination, and the will has the first place and the imagination has the second place, because it is taken from the will, he does not believe that God has become the creator in a certain time ago, when $\mathrm{He}$ created the truths of all incidents of beings and assets in all their possible parts forever by one word: "To be", and estimated the qualities and quantities of things whether they were spiritual or soulless - that can be happened forever. Then the creation of God gives them the status of being in the real world in those molds that are fixed in the conscience of God Almighty as fixed, static and decreed templates from the first, such as Plato's fixed dignitaries. Iqbāl denies the existence of such stereotypes that are fully detailed in god's almighty conscience. Iqbāl believes that the things exist in the ability of God's creation by force. This power has the infinite potential, but the resources and implications of that infinite potential emerge only in a time of creation. God almighty is the Creator first, but he will not be worthy to call him a true creator if he creates according to a previous plan or (a precedent reality) as Plato said in his ideal philosophy, meaning (a plan drawn from the first). Iqbāl disagrees with most philosophers and specialists in the religious affairs who tried to determine that the knowledge of things is preexisting, i.e. before they were created by God Almighty, and this determination from their side is against the ability of God's creation as he pleases and how he wishes. 
The second characteristic of Divine self, - which is strongly emphasized by Iqbāl - is unilateralism or His individual personality. Here Iqbāl is contrary to those Sufis and intellectuals who have chosen the path of oneness in the in abundance (Pantheism), which is known as "All is He" in Persian, and who explain this verse "He is the first, the last, apparent and the hidden" or the verse: "God is the light of the heaven and earth. Example of his light is as the light inside the lamp. Lamp is in a bottle, and the bottle is like a lightened planet..." in the light of the idea of (Pantheism), meaning that the divine-self overcomes the selves, personalities or individuals from all the creatures. Thus, all these beings lose their existence in the divine-self, which means that they want to annihilate themselves in the same of God, but Iqbāl believes that the interpretation of light in the verse with an illuminated star with its own certain self takes God Almighty out of the conception of the whole (Absolute soul). In the light of modern science and knowledge, Iqbāl wants that the same analogy of God, which is mentioned in the Torah, the Holy Gospel and the Qur'an- must be explained again in the light of modern science and knowledge.

He responds to those who think that the divine-self thus becomes limited in the case of proving the uniqueness of each individual being i.e. (creatures) or (the smaller Individual), and says that the uniqueness of the power of His infinite creation - in showing himself or granting full freedom to all individuals of creatures - was never limited, because the limitation by the adjective is nothing but a temporal and spatial perception.

On this basis, we see that things are always limited in the time and space, but the divine-self alone is not limited or infinite on the basis of time and space, because this measurement takes place on those things or incidents that exist in time and space. The absolute self (or the divineself) or (I am the absolute) is not infinite on the basis of time and space, but it is infinite on the basis of its infinite abilities, as this fact is represented in the form of these beings as a part of their infinite abilities, So divine-self is not infinite in terms of quantity, but it is infinite in terms of quality, creating a sequence of possibility of endless incidents, but it itself is not bound by that sequence, so God continues to create it, his creation is not an accident that has happened and it is over forever, the creation is an ongoing act, not an accident. The nature of the absolute self (the absolute self) is to create, and it only creates (self) or (individual). God does not create things, but creates individuals. Every atom of self or divine creatures is a self or an individual, whether smaller, larger, lower or higher in the levels of life. According to Iqbāl, the all levels of life are only the levels of self-advancement. So, my voice or the voice of the self gradually rises in all the melodies of life. Thus, Iqbāl transformed the world of "essence" to 'Ashā'ira into the spiritual abundance. According to Iqbāl, the divine-self is not quiet at all, but rather a dynamic flood, and all His creatures are manifestations of his infinite abilities, and they have also been created to create. Iqbāl believed that this was the conception of divinity in the Qur'an, and the Holy Hadith: (Don't insult the time) that provides us with this kinetic perception of the rotation of creation. (16)

Islam has revived the conception of the real existence of the divine-self with all strength and faith, and Islam has emphasized that the divine self is not a fake for an unknown absence that does not exist, but that the divineself has a great personality, which can have some relation to a man, but some Muslim thinkers who fell into the complex philosophies have changed the truth of the effective power of creation for the living and powerful divine-self, although the Holy Qur'an says that God almighty continues in his creations and every day He has a new status (creation). We felt that those enormous and strange possibilities that true Islam has provided them with to change the world have been lost from their hands. It is stated in the Qur'an that God almighty increases creation as he pleases. (17) So the universe as the whole with all its perfection was not suddenly created, and now he does not need any change, development or growth at all, but it is not strange that a new wish to be created again is hidden in the conscience of the will of the Creator (God Almighty), as God Almighty says: "God destroys the creation and then brings it back."(18) It means that Islam believes that God is alive and moving, and can change His will.

Iqbāl followed the doctrine of the great Sunni Islamic scholars in proving the existence of the divine-self. He said clearly that the existence of the living God Almighty is not proven by the mental proofs, because the proofs provided by the divine philosophers to prove the existence of the divine self are cosmic, lyrical or existential proofs and are merely an attempt to reach an unlimited self through the denial of the existence of a limited self, but the existence of the unlimited self can only be reached after the abolition of the existence of the limited self, because the existence of that infinite self itself invalidates the nullification of the existence of the limited self, because the ends only indicate the existence of a maker, nor on the existence of a creator. The proofs that they have provided to prove (the total truth) prove that the concept of (the perfect divine self) also includes that $\mathrm{He}$ is alive, but God that is mentioned in the Holy Qur'an and the other Holy Books of Heaven is a living that cannot be understood by the reason, and cannot be proved by the mental evidence without acknowledging that man's thought and existence together are ultimately one thing. (19)

Iqbāl believes that what we call the nature, it is nothing but a quick glimpse of the life of God Almighty, which is that called by the Qur'an (Nature of God Almighty), the existence of the true Creator (God Almighty) cannot be proved by the evidence derived from the nature itself, except with the conscience that reveals to us that life is a gathering of the self, God is "the self ", and to clarify the individuality of the self or the divine self a special name "Allah" has been used, but we must not repeat that the divine self is limited by this unilateralism, because we cannot imagine that god's infinite self is not limited after all the dimensions of the limited, but it is not infinite in terms of width, length, distance, height, and depth. So "the absolute self or the divine self" is unlimited on the basis of the possibilities of its unlimited capabilities of creation, and this universe is a partial manifestation of its creative abilities, as it is mentioned before.

Nature is a primitive experience of the creative God who created it as a laboratory of experiments to prepare strange artifacts, the character of creation, as it is mentioned in the Qur'an, is the most prominent of all the attributes of God, therefore Islam has always emphasized it until the actions of man were also considered that they are created by God, in order to keep this theory right, which says that God is the absolute creator. Therefore, 'Ashā'ira chose the doctrine of "essence", which means creating the world from the indivisible essence that 'Ashā'ira call "the essence", because the work of god's creation continues, creating a new essence every moment. God almighty has given the essences the spirit of life that we call things, and according to their nature it is a complex set of essential works, there is nothing that has a certain nature. This perception that the nature of beings is not subject to a certain system and limited origins makes God free in his creation, and from this perception we find the proof of existence of divine self or an individual self for God 
the Creator who produces some positive results from a group of essences that have no system, but they were installed, assembled or configured accidently, so we observe the beauty and survival in the results of God Almighty's creations. It is the work of the great "Divine self", God, who has come together with thought and existence (or life). He is the owner of creation and command. What is meant by creation is the work of synthesis, which continues in these beings that accept evolution and expansion. What is meant by the "command" is one of the qualities of His creation, which is related to the world of spirits.

According to Iqbāl, God has also given the man the power of creation that makes him the controller for the material things. Iqbāl imagines that things are not rigid that do not accept any change. He imagines also that a true believer is able to create new things, as it is considered a new addition to what is found in the beings that are counted by Iqbāl (the nature of God) or (the primitive experience) of God the absolute creator. If human beings' abilities are in line with God Almighty's abilities the human can make the miracles, and he can discover always unknown facts.

Human being has the responsibility to carry it from a great personality that has an absolute freedom. \{The responsibility was presented to the skies, the earth and the mountains, they denied to carry it, but the human carried it $\ldots$... (20) The personality of man is (his individuality) or his same that arose in the abstract time, and it did not exist before its arising in the time and the space, and as stated in the Holy Qur'an there is no possibility of its returning to this world again after moving from here. So it has a beginning and an end that shows that its worldly life is limited, but its end is not because of its misfortune, because its unilateralism never can be change, and by its individuality it reaches the presence of (Unlimited Individual) means the divine self. The Holy Qur'an does not consider the surviving the end to be the great happiness of man. This proves that the time is real, and the life is a constant movement in the rotation of time, but if we had said that the movement was in a circle, the movement would not have remained as the movement of creation. We must accept that the time is a straight line that has an extension from Iqbāl's point of view.

So who are those individuals who have matured their personalities and their selves mean (Individuality) reached the perfection in the eyes of Iqbāl? Immortality or survival is not the right of man, but the stage of immortality or survival can be reached by the effort, and immortality or eternal life is in the opinion of Iqbāl a state of life, as he said in Zabūr -e-'Ajam:

"Cramming bodies is a state of life, and cramming bodies is a symbolic evidence of not completely annihilating oneself." (21)

So what is the way to eternity and survival? It is in the opinion of Iqbāl the obedience, it means obedience to God and His Messenger, and the restraint. This method is not easy for the general public, but it can be reached to the degree of perfection, the degree of (the complete human), the degree of (His slave) or the degree of divine prosecution, which is the degree of God's successor in the earth, i.e. the deputy of God Almighty in the earth, and when the man reaches such a high degree of selfadvancement: (Individuality) his hand becomes the hand of God. Immortality or survival is the goal, not annihilation in the divine self as Sufism sees it in the doctrine of (the unity of existence) or (Pantheism).

\section{CONCLUSION}

There is no doubt that Iqbāl, after reading the chronic and inaction situation filled with contradictions to the East in general and India in particular, identified some measures for its analysis and treatment, and he as a reformer or pioneer looked at his nation through the perspective of the West and modern thinking, but was not fooled by the civilization of the West or the human being of the West, because he was able to differentiate between two elements that are clear to Western civilization:

The first is the movement of scientific progress developing thanks to modern scientific approaches, and the continued efforts of creativity, innovation, detection and invention to control the nature and harness the system of the universe.

The second, imperialism and materialism, with its racial, material and atheistic segregation in the hearts of the Western human being, may represent every injustice in the abhorrent Western colonialism that surrounded the entire Muslim East.

This difference between the two distinct elements that are reflected in the structure of Western civilization has defined the way for his regenerative journey, as he already believes in the superiority of Islam above all, where he believes that Islam is capable of providing the Muslim with full effectiveness to recognize and control the reality without backwardness or tradition of civilization. The West believes in the genius of science and its objective approaches and results that are the results of joint efforts of all humanity, because Muslims have also made a significant contribution to the development of these sciences, and even the objective results of scientific researches of Muslims were the nucleus of modern Western civilization.

\section{REFERENCES}

[1] Surat al-Najm, Verse: 40-41

[2] Surat al-Dukhān: 38-39

[3] Surat Āl- 'Imrān: 190-191

[4] Surat al- 'Ankabūt: 20

[5] Muhammad Iqbāl. (1968). Reconstruction of religious thoughts in Islam. Translated into Arabic by 'Abbās Mahmūd, and reviewed by 'Abdul 'Azīz Al-Marāghī. Cairo: P. 19

[6] Surat al-Baqara, Verses: 30, 31, 32, 33

[7] Ibid. P. 21

[8] Ibid. P. 22

[9] Muhammad Iqbāl. (1968). Reconstruction of religious thoughts in Islam. P. 7

[10] Ibid. P. 13

[11] Faḍl al-Rahman. (1955). Islamic culture and contemporary life or (modern Islamic philosophy). Cairo: Egyptian Renaissance Library. P. 86

[12] Muhammad Iqbāl. (1968). Reconstruction of religious thoughts in Islam. P. 13 
[13] Sahīh Al-Bukhārī, P. 96 Printed in Offset - Dār al-Fikr Istanbul and See Șahīh Al-Bukhārī/Book of Jihad. P. 32 See true Muslim. P. 46 Part 18. Bayān Ibn Șayyād. Egyptian Printing Press. Egypt. See: in the eye Badruddīn 'Abu Muhammad Mahmūd b. 'Ahmmad. (1972). 'Umdat Al-Qārī in the explanation of Șahịh alBukhari. Cairo: First edition. Muștafa Al-Bābī Al-Halabì Press. Part 7. p. 85-86. See also: 'Asqalānī. 'Aḥmad b. 'Alī b. Hajar. (No date). Fatah al-Bārī. Cairo: Library of AlHudā. Al-Muhammadī Mosque. P 3 (773-853). P. 218

[14] Muhammad Iqbāl. (1968). Reconstruction of religious thoughts in Islam. P. 212

[15] Al-Katānī. Muhammad. (1978). Muhammad Iqbāl as an Islamic thinker. Casablanca: House of Culture First Edition - P. 54
[16] Urdu Magazine: Māh -e- Naw. Special issue about Muhammad Iqbāl. (September 1977). Pakistan.

[17] Surat Fāțir: 1

[18] Surat al- 'Ankabūt: 19

[19] Muḥammad Iqbāl. (1968). Reconstruction of religious thoughts in Islam. P. 39-40

[20] Surat al-'Aḥzāb: 72

[21] Muḥammad Iqbāl. Zabūr - e - 'Ajam - (Divan of Persian Poetry). 